Journal of Applied Pharmaceutical Science Vol. 5 (06), pp. 115-119, June, 2015

Available online at http://www.japsonline.com

DOI: 10.7324/JAPS.2015.50619

ISSN 2231-3354 (cc) BY-NC-SA

\title{
Effect of chronic Consumption of two Forms of palm oil diet on serum Electrolytes, Creatinineand urea in rabbits
}

\author{
Elemi J. Ani, Victor U. Nna, Daniel U. Owu, Eme E. Osim \\ Department of Physiology, Faculty of Basic Medical Sciences, College of Medical Sciences, University of Calabar, P.M.B. 1115, Calabar, Nigeria.
}

\begin{tabular}{l} 
ARTICLE INFO \\
\hline Article history: \\
Received on: $05 / 03 / 2015$ \\
Revised on: $21 / 03 / 2015$ \\
Accepted on: $14 / 04 / 2015$ \\
Available online: $27 / 06 / 2015$ \\
\hline Key words: \\
Creatinine, fresh palm oil, \\
serum electrolytes, \\
thermoxidized palm oil, urea
\end{tabular}

\begin{abstract}
Palm oil is one of the most widely employed cooking oils in Nigeria today. This study compares the effects of long term consumption of the two forms of palm oil - fresh palm oil (FPO) and thermally oxidized palm oil (TPO) on serum electrolytes, creatinine and urea, which gives vital information on the state of the renal system. Eighteen male New Zealand rabbits weighing 750 - $1000 \mathrm{~g}$ were used for this study. They animals were randomly assigned one of three groups $(n=6)$ thus; control group, FPO fed group and TPO fed group. The control group received animal feed and clean water only. Fresh palm oil group received animal feed mixed with fresh palm oil in the ratio 85:15g respectively, TPO fed group received animal feed mixed with thermoxidised palm oil in the ratio 85:15g respectively. The feeding lasted for 6 months. Food intake, water intake and body weight were measured daily. At the end of the feeding period, the animals were sacrificed under chloroform anaesthesia and blood was collected for assessment of serum electrolytes, creatinine and urea. Results obtained showed that serum concentration of sodium was significantly $(\mathrm{p}<0.001)$ lower in FPO fed group, compared with control, but significantly $(\mathrm{p}<0.05)$ higher in TPO fed group, compared with control. Serum concentration of sodium was also significantly $(\mathrm{p}<0.001)$ higher in TPO fed group, compared with FPO fed group. Serum concentration of chloride was significantly lower in FPO fed group compared with control $(\mathrm{p}<0.05)$ and TPO fed group $(\mathrm{p}<0.001)$. Bicarbonate concentration was significantly $(\mathrm{p}<0.05)$ lower in FPO fed group, compared with control. Creatinine concentration was significantly higher $(\mathrm{p}<0.05)$ in TPO fed group, compared with control and FPO fed group. The observed changes in serum electrolyte and creatinine concentrations following 6 months of feeding was more in TPO fed group than FPO fed group, and is possibly detrimental to electrolyte balance.
\end{abstract}

\section{INTRODUCTION}

Palm oil is one of the most widely used cooking oils in West and Central Africa. It originated from Africa and has now spread throughout most of the world (Mukherjee and Mitra, 2009). It is a common cooking ingredient in the tropical belt of Africa, Southeast Asia and parts of Brazil. Its increasing use in the commercial food industry in other parts of the world is enhanced by its lower cost, and the high oxidative stability (saturation) of the refined product when used for frying (CheMan et al., 1999; Matthaus, 2007). Palm oil is the most widely produced vegetable oil in most parts of Africa, especially Nigeria where it is consumed mainly in the fresh and thermally oxidised forms (Cotrell, 1991; Osim et al., 1994; Ebong et al., 1999).

\footnotetext{
* Corresponding Author

Elemi J. Ani, Department of Physiology, Faculty of Basic Medical Sciences, College of Medical Sciences, University of Calabar, P.M.B. 1115, Calabar, Nigeria. Email: mail id: eljani21 [at] yahoo.com
}

Oils are generally thermally oxidised to render them highly palatable. However, this thermoxidation is said to have deteriorative effects on the body (Perkins and Van-Akkerren, 1965; Isong, 1988).

Some researchers have previously shown that uncontrolled thermal oxidation of fats and oils leads to formation of peroxides and other products which are known to be very reactive, cytotoxic and destructive to tissues (Plea, 1975; Frankel, 1980; Ziombski, 1982). The oxygen derived free radicals and dihydroxy esters contained in thermoxidised palm oil have been demonstrated to cause injury to cells (Ebong et al., 1999; Isong et al., 1992; Owu et al., 1998; Edem, 2002; Felzenszwalb et al., 2014; Osim et al., 1992).

This study therefore compares the effects of long term intake of the two forms of palm oil (fresh palm oil and thermally oxidized palm oil) on serum electrolytes, creatinine and urea, which gives vital information on the state of the renal system. 


\section{MATERIALS AND METHODS}

\section{Experimental Animals}

Eighteen male, New Zealand rabbits weighing 750-1000 $\mathrm{g}$ at the onset were used for this study. They were divided into three groups of six rabbits each. The first group (control group) was fed with animal feed and clean water only. The second group (FPO diet group) received animal feed mixed with fresh palm oil, while the third group (TPO diet group) received animal feed mixed with thermoxidised palm oil. The animals were kept in separate cages in the animal house of the Department of Physiology, at room temperature and away from direct sunlight. Their cages were cleaned daily and a high level of sanitation was generally maintained in and around the animal house.

\section{Preparation of Palm Oil Diets}

Twenty liters of palm oil from the oil palm tree Elaesis guneensis were used for this study. The oil was purchased from a local oil mill in Odukpani, Cross River State, Nigeria. The oil was divided into two equal parts. One part was kept as fresh palm oil (FPO) while the other part was thermally oxidized to yield thermoxidised palm oil (TPO).

These are the two common forms of palm oil used for cooking in Nigeria. Each type of oil was used to prepare their respective diets. Thermoxidation of the palm oil was done as described by Isong et al., (1992). Briefly, fresh palm oil was heated in a stainless steel pot over a heating mantle at a temperature of $150^{\circ} \mathrm{C}$.

This heating was done five times, each session lasting for twenty minutes. The oil was allowed to cool for five hours in between sessions. Both diets were stored in black containers at $4^{\circ} \mathrm{C}$ to prevent further oxidation of the oil component. Fresh palm oil diet was prepared by mixing $15 \mathrm{~g}$ of fresh palm oil with $85 \mathrm{~g}$ of feed while thermoxidised palm oil diet was prepared by mixing $15 \mathrm{~g}$ of thermoxidised palm oil with $85 \mathrm{~g}$ of feed (Ani et al., 2014).

This diet formulation was based on the fact that most Nigerian dishes contain about $15 \%$ of palm oil, as reported by Umoh, (1972). The rat feed (Pfizer) consisted of $21 \%$ protein, $3.3 \%$ fat, $6 \%$ fiber, $0.8 \%$ calcium and $0.8 \%$ phosphorous.

The feeding period lasted for 6 months, after which the animals were used for the various experiments.

\section{Determination of Food and Water Intake}

Food and water intake was measured at 12 noon daily. The water intake was derived by subtracting the volume of water left in the container after 24 hours from the initial volume earlier introduced. Food intake involved weighing the amount of food left in the feeding container after 24 hours and subtracting it from the initial weight of food introduced the previous day. Both food and water containers were attached to the cages to stabilize them and check spillage. Throughout the feeding period, individual food and water intake was measured daily while the animals were weighed weekly.

\section{Determination of Electrolytes, Urea and Creatinine in Plasma}

The electrolytes measured in this study were sodium $\left(\mathrm{Na}^{+}\right)$, potassium $\left(\mathrm{K}^{+}\right)$, chloride $\left(\mathrm{Cl}^{-}\right)$, bicarbonate $\left(\mathrm{HCO}_{3}^{-}\right)$and calcium ions $\left(\mathrm{Ca}^{2+}\right)$. Urea and creatinine were also measured. Blood samples from the different groups of animals were collected by cardiac puncture and allowed to stand for three minutes after which they were centrifuged and the serum collected for assay.

The tritrimetric, mercuric nitrate method of Schales and Schales, (1941) was used for measurement of $\mathrm{Cl}^{-}$. Bicarbonate concentration was measured using the back titration method, as described by Rosenfeld (1999). Plasma concentration of calcium was measured using the O-cresolphthalein complexone (CPC) method of Connerty and Biggs (1966). Urea concentration was measured using the diacetylmonoxime method of Fearon (1939), as described by Rahmatullah and Boyde (1980), while creatinine concentration was measured using the method described by Deepa (2011).

\section{Histological Studies}

The kidney was harvested and processed with haematoxylin and eosin stains. The tissues were fixed in $10 \%$ neutral formalin after which they were dehydrated using alcohol and cleaned in xylene.

The tissues were then embedded in paraffin wax and thin sections cut at five microns. The sections were stained with haematoxylin for 15 minutes, differentiated with $1 \%$ acid alcohol, counter stained in eosin for two minutes and mounted with DPX biological mounter. The sections were viewed under the microscope (magnification, X100) and photomicrographs taken.

\section{Statistical Analysis}

All data are shown as mean \pm SEM. The One-way analysis of variance (ANOVA) was used to analyze the data. Values of $p<0.05$ were considered significant Computer software SPSS and excel analyzer were used for the analysis.

\section{RESULTS}

\section{Comparison of mean monthly food intake in the different experimental groups}

Figure 1 shows a comparison of mean monthly food intake (g) in the different experimental groups. It shows the average quantity of food eaten at the beginning of the experiment to be $95.5 \pm 0.06,71.41 \pm 1.58$ and $85.2 \pm 1.74$ for control, FPO and TPO respectively. This rose to an average of $115.04 \pm 0.09$, $114.91 \pm 0.01$ and $114.92 \pm 0.01$ respectively at the end of six months.

\section{Comparison of mean monthly water intake in the different experimental groups}

Figure 2 shows a comparison of the mean monthly water intake in the different experimental groups. It shows that at the onset of the experiment, mean water intake for control, FPO and 
TPO groups was $86.65 \pm 3.16,72.34 \pm 2.2$ and $60.67 \pm 0.06 \mathrm{ml}$ respectively. At the end of six months, this rose to $168.61 \pm 1.68$, $139.89 \pm 2.06$ and $166.67 \pm 0.0$ respectively. The FPO group was significantly lower than the control and TPO groups $(\mathrm{P}<0.001)$.

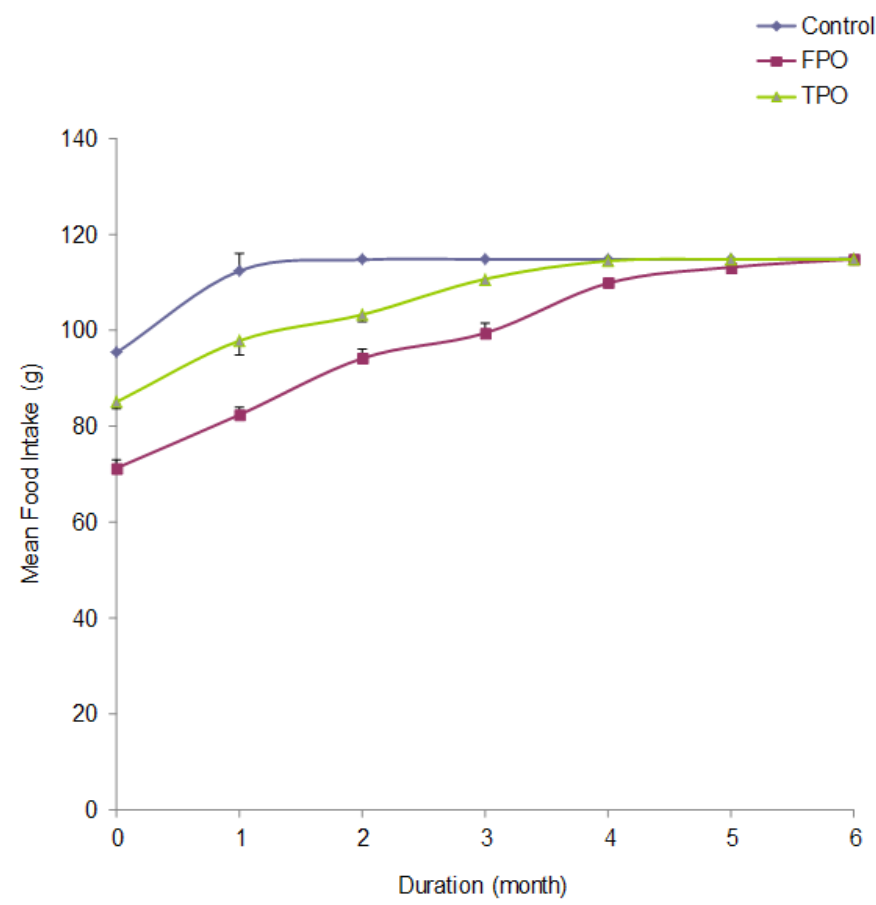

Fig. 1: Comparison of mean monthly food intake in the different experimental groups. Values are mean $\pm S E M, n=6$.

\section{$\rightarrow$ Control \\ $\rightarrow-F P O$ \\ $\rightarrow$ TPO}

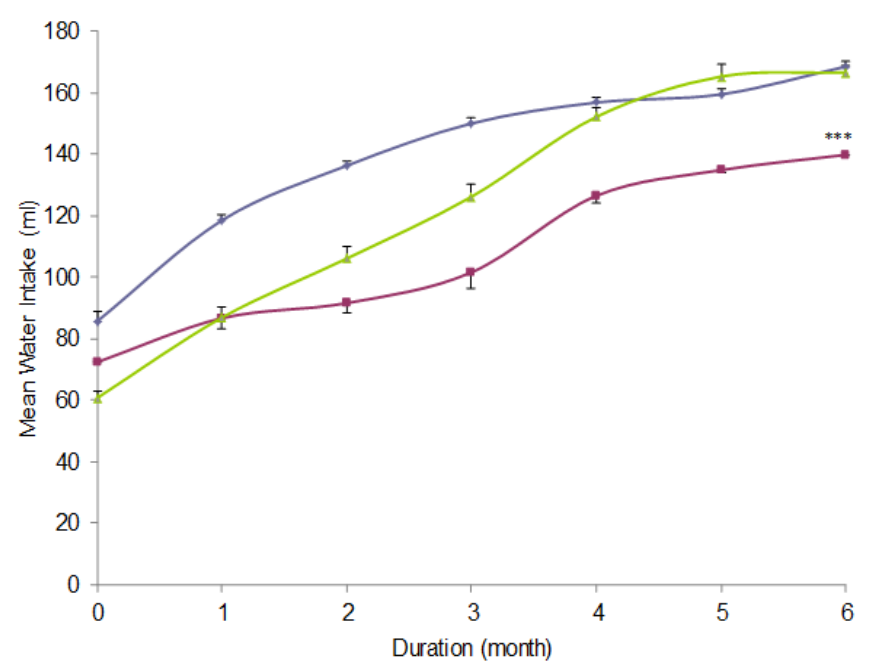

Fig. 2: Comparison of mean monthly water intake in the different experimental groups. Values are mean \pm SEM, $n=6$. $* * * p<0.001$ vs Control \& TPO.

\section{Comparison of mean monthly body weights in the different experimental groups}

Figure 3 shows that the mean body weight at the onset (g) for the control, FPO and TPO groups was $970.83 \pm 13.3$,
$850.00 \pm 38.62$ and $916.67 \pm 14.97 \mathrm{~g}$ respectively. There was no significant difference in the initial body weights. This rose to $1812.5 \pm 34.22,1720 \pm 40.53$ and $1554.17 \pm 46.38 \mathrm{~g}$ respectively, at the end of six months.

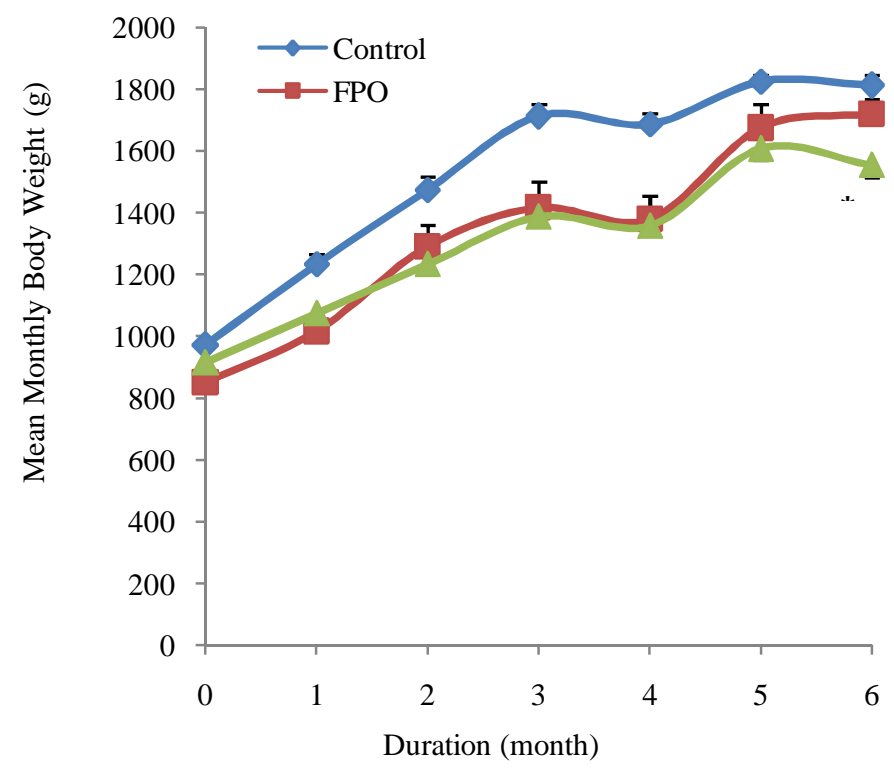

Fig. 3: Comparison of mean monthly body weights in the different experimental groups. Values are mean $\pm \mathrm{SEM}, \mathrm{n}=6, * * \mathrm{P}<0.01$ vs control

\section{Comparison of Serum Electrolytes, Creatinine and Urea Concentrations in the different Experimental groups}

Serum concentration of sodium was significantly $(\mathrm{p}<0.001)$ lower in FPO treated group, compared with control, while TPO fed group showed a significantly $(\mathrm{p}<0.05)$ higher serum sodium concentration, compared with control. Serum concentration of sodium was also significantly $(\mathrm{p}<0.001)$ higher in TPO fed group, compared with FPO fed group (Table 1). Serum concentration of chloride was significantly lower in FPO fed group compared with control $(\mathrm{p}<0.05)$ and TPO fed group $(\mathrm{p}<0.001)$. Bicarbonate concentration was significantly $(\mathrm{p}<0.05)$ lower in FPO fed group, compared with control. Creatinine concentration was significantly higher $(\mathrm{p}<0.05)$ in TPO fed group, compared with control and FPO fed group (Table 1).

Table 1: Comparison of serum electrolytes, creatinine and urea concentrations in the different experimental groups.

\begin{tabular}{lccc}
\hline Parameter & Control & FPO & TPO \\
\hline Sodium $(\mathbf{m m o l} / \mathbf{L})$ & $133.67 \pm 0.61$ & $128.17 \pm 1.28^{* *}$ & $138.17 \pm 1.66^{*, \mathbf{c}}$ \\
Potassium $(\mathbf{m m o l} / \mathbf{L})$ & $5.78 \pm 0.36$ & $6.03 \pm 0.13$ & $5.75 \pm 0.16$ \\
Chloride $(\mathbf{m m o l} / \mathbf{L})$ & $97.67 \pm 1.89$ & $92.83 \pm 0.83^{*}$ & $99.00 \pm 0.45^{\mathbf{c}}$ \\
Bicarbonate $(\mathbf{m m o l} / \mathbf{L})$ & $21.33 \pm 1.26$ & $18.33 \pm 0.33^{*}$ & $19.17 \pm 0.60$ \\
Calcium $(\mathbf{m m o l} / \mathbf{L})$ & $2.10 \pm 0.07$ & $2.13 \pm 0.03$ & $2.10 \pm 0.04$ \\
Creatinine $(\mathbf{m m o l} / \mathbf{L})$ & $127.45 \pm 4.07$ & $136.48 \pm 2.68$ & $140.55 \pm 2.53^{*, a}$ a \\
Urea $(\mathbf{m m o l} / \mathbf{L})$ & $5.33 \pm 0.66$ & $3.78 \pm 0.62$ & $4.60 \pm 0.48$
\end{tabular}

Values are mean \pm SEM, $\mathrm{n}=6 .{ }^{* *} \mathrm{p}<0.01,{ }^{*} \mathrm{p}<0.05$ vs Control; $\mathrm{c}=\mathrm{p}<0.001, \mathrm{a}$ $=\mathrm{p}<0.05 \mathrm{vs}$ FPO 


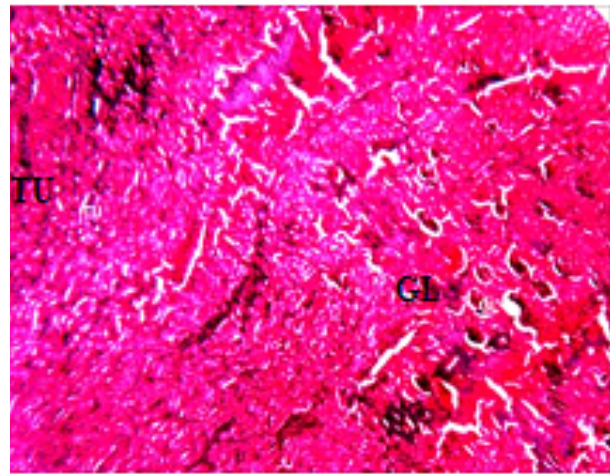

(a)

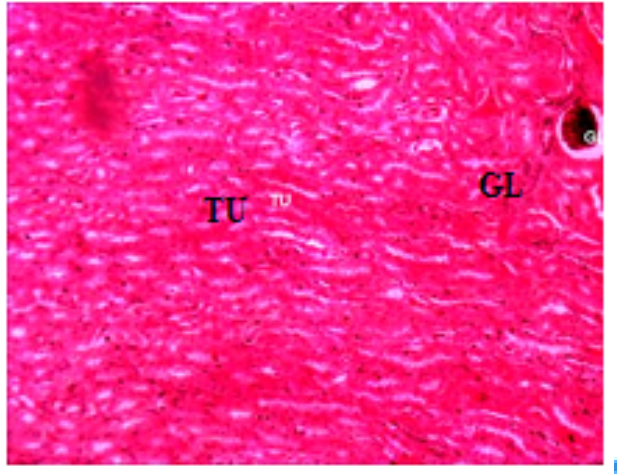

(b)

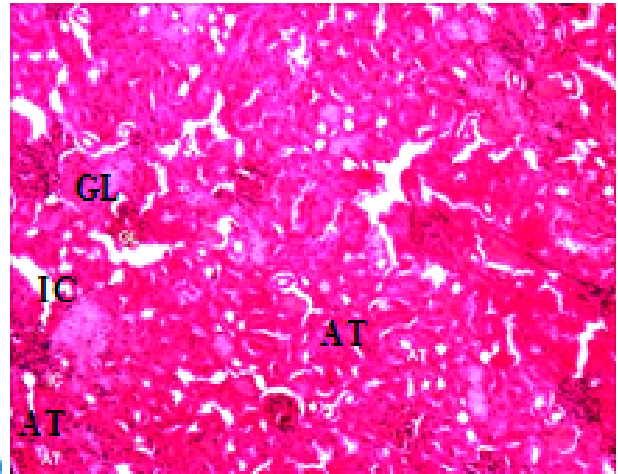

(c)

Plate 1: Photomicrograph of a cross section of the kidney in (a) control (b) FPO and (c) TPO group stained with H \& E. Magnification x100 Key: $\mathrm{GL}=$ glomerulus, $\mathrm{TU}=$ tubule, $\mathrm{AT}=$ atrophic tubule, $\mathrm{IC}=$ inflammatory cells.

\section{Photomicrographs of the kidney in the different experimental groups}

Plate 1 shows photomicrographs of the kidney in (a) control, (b) FPO and (c) TPO fed group. Plate 1a (control group) shows normal glomeruli (GL) and tubules (TU). The kidney architecture is essentially normal. The FPO fed group also shows normal kidney architecture. The TPO fed group on the other hand, shows infiltration by inflammatory cells (IC)(glomerulonephiritis). There are also atrophic tubules (AT) and tubule-interstitial nephritis, with progressive tubular destruction. There is narrowing of the Bowman's space and vasculitis in some areas.

\section{DISCUSSION}

The serum electrolytes measured in this study were sodium $\left(\mathrm{Na}^{+}\right)$, potassium $\left(\mathrm{K}^{+}\right)$, chloride $\left(\mathrm{Cl}^{-}\right)$, bicarbonate $\left(\mathrm{HCO}_{3}{ }^{-}\right)$ and calcium ions $\left(\mathrm{Ca}^{2+}\right)$. The serum sodium ion level in the thermoxidised palm oil group was significantly higher than that of the control and fresh palm oil group while the fresh palm oil group had sodium levels significantly less than the control.

Chloride ion was significantly increased in the thermoxidised palm oil group when compared to the fresh palm oil group, which was significantly less than the control.

Potassium and calcium ions showed no significant change among the three groups while bicarbonate was significantly reduced in the fresh palm oil group, when compared to the control.

The increase in sodium concentration in the thermoxidised palm oil group may be as a result of modulation by plasma cholesterol in this group. Previous studies have shown that chronic consumption of thermoxidised palm oil diet increases the level of total and LDL cholesterol (Osim et al., 1996; Owu et al., 1997; Ani et al., 2015) and induces an adverse plasma lipid profile (Gorburdhun and Jhurree, 1995; Larsen et al., 1997). Cholesterol is a key regulator of the fluidity of the cell membrane (Luber, 1988). Its presence in the membrane makes molecules of phospholipids pack more closely together. Therefore, cells with high concentration of cholesterol in their membranes are less fluid
(Shanmugasundaran et al., 1986). This affects the transmembrane movement of sodium, indicating that cholesterol plays a modulatory role in transmembrane transport. This position was also upheld by another group of researchers, who concluded their study by stating that hypercholesterolaemia was associated with an increase in plasma sodium concentration in the population studied, and that the population was at risk of developing hypertension (Tippins et al., 2000).

The increase in plasma sodium ions in the thermoxidised palm oil group may also explain why chloride ion concentration was highest in TPO group. It is established that, as the concentration of sodium increases, chloride follows to maintain electrochemical equilibrium and this is the probable reason chloride concentration was higher in the thermoxidised palm oil diet-fed group. The increased osmolarity of the plasma that results draws more fluid in and expands the volume of the extracellular fluid. This increases plasma volume. The significant increase in serum creatinine concentration in the thermoxidised palm oil group may be suggestive of possible renal system damage. Creatinine levels in plasma are usually measured to determine acute or chronic renal insufficiency (Luber, 1988). They are usually raised in renal disease. Histology of the kidney (plate 1) shows that the kidneys in TPO group were actually damaged in this study. Urea concentration however, was not significantly altered in the three experimental groups.

\section{CONCLUSION}

The observed changes in some serum electrolytes and creatinine concentrations following 6 months of feeding was more in TPO fed group than FPO fed group which showed significant changes suggestive of a compromised renal status. This was further supported by a deranged histology of the kidneys in this group. Therefore, consumption of TPO diet should be moderated or completely avoided.

\section{REFERENCES}

Ani, E. J., Nna, V. U., Okon, U. A., \& Ekpenyong, C. E. Effect of Aloe vera gel on thermoxidized palm oil-induced derangements in some 
haematological and biochemical parameters. Der Pharmacia Lettre, 2014; 6(6):448-452.

Ani, E. J., Ofem, O. E., V. U. Nna, Jacob, M. U. Alteration in serum lipid profile following chronic consumption of thermally - oxidized palm oil and groundnut oil - modified diets in rats. Research Journal of Pharmaceutical, Biological and Chemical Sciences, 2015; 6(2): 634 - 641.

CheMan, Y. B., Lu, J. L., Camilah, B., Rahman, R. \& Abdul, I. Quality changes of RBD palm olein, soybean oil and their blends during deep-fat frying. Journal of Food Lipids, 1999 ; 6(3): 181 - 193.

Connerty, H. V. \& Biggs, A. R. Determination of serum calcium by means of orthocresolphthalein complexone. American Journal of Clinical Pathology, 1966; 45(3), 290 - 296.

Cotrell, R. C. Nutritional aspects of palm oil. American Journal of Clinical Nutrition, 1991; 53: 989S-1009S.

Deepa, K., Manjunatha, B. K., Oinam, S. D., Devaki, R. N., Bhavna, N., Asha, P. \& Naureen, A. Serum urea, creatinine in relation to fasting plasma glucose levels in type two diabetic patients. International Journal of Pharmacy and Biological Sciences, 2011, 1(3): 279 - 283.

Ebong, P. E., Owu, D. U. \& Isong, E. U. Influence of palm oil (Elaesis guineensis) on health. Plant Food for Human Nutrition, 1999; 53: $209-222$.

Edem, D. O. Palm oil: Biochemical, physiological, nutritional, hematological and toxicological aspects: A review. Plant Foods for Human Nutrition, 2002; 57(3-4): 319-341.

Fearon, W. R. The carbanido diacetyl reaction: A test for citrullin. Biochemical Journal, 1939; 33, 902.

Felzenszwalb, I., da Costa Mazzei, J. L., Feitosa, S., Fortes Aiub, C. A., \& de Almeida, D. T. Toxicological assessment of crude palm oil (Elaeis guineensis Jacq.) used in deep frying of akara (cowpea paste finger food). Grasas y Aceites, 2014; 65(2): e020. $1980 ; 19,22$

Frankel, E. N. Lipid oxidation programme. Lipid Research,

Gorburdhun, D. \& Jhurree, B. Effect of deep fat frying on fat oxidation in soya oil. International Journal of Food Science Nutrition, 1995; 46 (4): 363 - 371.

Isong, E. U. 1988. Biochemical and nutritional studies on rat of thermally oxidised palm oil (Elaesis guineensis). Unpublished Ph.D thesis, University of Calabar, Nigeria.

Isong, E. U., Ifon, E. T., Eka, O. U., Essien, E. U. \& Umoh, I. B. Effect of intermittently thermoxidised palm oil on normal and malnourished rats. Tropical Journal of Applied Sciences, 1992; 2:118-121.

Isong, E. U., Ifon, E. T., Eka, O. U., Essien, E. U. \& Umoh, I. B. Effect of intermittently thermoxidised palm oil on normal and malnourished rats. Tropical Journal of Applied Sciences, 1992;2:118- 121.

Larsen, L. F., Bladbjerg, E. M., Jespersen, J. \& Marckmann, P. Effects of dietary fat quality and quantity on postprandial activation of blood coagulation factor VII. Arteriosclerosis Thrombi Vascular Biology, 1997; 17(11): $2904-9$.

Luber, S. 1988. Biochemistry $\left(3^{\text {rd }}\right.$ ed.). New York: W. H. Freeman, $80-89$.

Matthaus, B. Use of palm oil for frying in comparison with other high-stability oils. European Journal of Lipid Science and Technology, 2007; 109: 400.

Mukherjee, S. \& Mitra, A. Health effects of palm oil. Journal of Human Ecology, 2009;26: 197 - 203.

Osim, E. E., Owu, D. U. \& Etta, K. M. Arterial pressure and lipid profile in rats following chronic ingestion of palm oil diets. African Journal of Medical Sciences, 1996; 25: 335 - 340
Osim, E. E., Owu, D. U., Isong, E. U. \& Umoh, I. B. Influence of chronic consumption of thermoxidised palm oil diet on platelet aggregation in the rat. Discovery and Innovation, 1992; 4 (1): 83 - 87.

Osim, E. E., Owu, D. U., Isong, E. U. \& Umoh, I. B. Influence of chronic consumption of thermoxidised and fresh palm oil diets on basal metabolic rate, body weight and morphology of tissues in rats. Discovery and Innovation, 1994; 6: $389-396$.

Owu, D. U., Osim, E. E. \& Ebong, P. E. Serum liver enzymes profile of wistar rats following chronic consumption of fresh or oxidised palm oil diets. Acta Tropica, 1998; 69: 65-73.

Owu, D. U., Osim, E. E. \& Orie, N. N. Altered responses of isolated aortic smooth muscle following chronic ingestion of palm oil diets in rats. African Journal of Medical Sciences, 1997; 26: 83 - 86.

Perkins, E. G. \& Van-Akkerren, L. A. Heated fats, IV: Chemical changes in fats subjected to deep fat frying processes. Journal of American Oil Chemists Society, 1965; 42: $101-106$.

Plea, R. M. Protein synthesis and absorption in rats fed with oxidised oil. Practitioner, 1975; 224: 306 - 421.

Rahmatullah, M. \& Boyde, T. R. Improvements in the determination of urea using diacetyl monoxime: methods with and without deproteinisation. Clinica Chimica Acta, 1980; 107(1-2): 3 - 9.

Rosenfeld, L. (1999). Four centuries of clinical chemistry. Florida: Chemical Rubber Company Press, $72-75$.

Schales, O. \& Schales, S. S. A simple and accurate method for the determination of chloride in biological fluids. Journal of Biological Chemistry, 1941; 140: 879.

Shanmugasundaran, K. R., Visvanthan, A., Dhandapan, K., Srinirasan, N., Rasappon, P., Gilbert, R., Alladi, S., Kancharilla, S. \& Vasanthin, N. Effect of high fat diet on cholesterol distribution in plasma lipoprotein, cholesterol esterifying activity in leucocytes and erythrocyte membrane components studied: Importance of body weight. American Journal of Clinical Nutrition, 1986; 44 (6): 805-815.

Tippins, R. B., Torres, W. M., Baumgartner, B. R. \& Baumgarten, D. B. Are screening serum creatinine levels necessary prior to outpatient computerised tomography examinations? Radiology, 2000; $216,481-484$.

Umoh, I. B. 1972. Changes in the nutritive values of some Nigerian diets after cooking by certain south eastern traditional methods. Unpublished Ph.D. thesis, University of Ibadan, Nigeria.

Ziombski, H. Physical, chemical and nutritional changes in heated fats. Changes in nutritive value. Raezinki Panstwocoego Zadkaladu Higieny, 1982; 33(3), $162-170$.

\section{How to cite this article:}

Elemi J. Ani, Victor U. Nna, Daniel U. Owu, Eme E. Osim. Effect of chronic Consumption of two Forms of palm oil diet on serum Electrolytes, Creatinine and urea in rabbits. J App Pharm Sci, 2015; 5 (06): 115-119. 